\title{
Obtaining Modified Bitumen Rubber Crumb for Cold-Rolled Roofing Materials
}

\author{
Andriy Nagurskyy $^{1}$, Oleg Grynyshyn ${ }^{2}$, Yuriy Khlibyshyn ${ }^{3}$, Taras Chervinskyy ${ }^{2}$, \\ Bohdan Korchak ${ }^{4}$ \\ 1. Department of Chemical Engineering, Lviv Polytechnic National University, UKRAINE, Lviv, \\ S. Bandery street 12, E-mail: andrii.o.nahurskyi@lpnu.ua
}

2. Department of Chemical Technology of Oil and Gas Processing, Lviv Polytechnic National University, UKRAINE, Lviv, S. Bandery street 12, E-mail: ogrynyshyn@ukr.net

3. Department of Organic Products Technology, Lviv Polytechnic National University, UKRAINE, Lviv, S. Bandery street 12, E-mail: yuriy_h@polynet.lviv.ua

4. Department of Civil Safety, Lviv Polytechnic National University, UKRAINE, Lviv, S. Bandery street 12, E-mail: kor4ak93@gmail.com

\begin{abstract}
The method of obtaining a bituminous composition, which can be used in the manufacture of cold-applied roofing materials using rubber crumb, is developed. The optimum content of components of a three-component bitumen composition is established.
\end{abstract}

Keywords - bitumen, bitumen composition, linseed oil, roofing materials, rubber crumb

\section{Introduction}

Roofing materials based on bitumen are very common in the Ukrainian market. Soft roof is widely distributed on the area of cottage houses and industrial buildings. The undoubted advantage is its complete dispersion to corrosion and decay. Moreover, meat tastes have excellent thermal insulation qualities. And thanks to the small weight, a soft roof can even be used to cover light wooden structures.

Roofing materials must have durability, water resistance, heat resistance and be resistant to atmospheric influences [1]. Also, they must be elastic enough to prevent cracks and tears from occurring due to shrinkage, temperature and other deformations of the insulated constructions. Nowadays, all the more popular are roofing and insulating materials of cold drawing. The advantage of these materials is a short lead time and ease of installation.

Bitumen from which roofing materials are made are very sensitive to temperature fluctuations and various atmospheric influences, especially to ultraviolet rays. Their negative property is low frost, which makes the coating short-lived. Although bitumen materials are the cheapest, but because the life of such a roof does not exceed 5-7 years and the total cost of supporting the roof in order for 30-40 years is quite significant. The disadvantage of well-known today's cold-drawing materials is the lack of adhesion, poor high temperature and low temperature properties [2].

\section{Experimental}

The first stage in the production of cold-drawn bituminous materials was the study of the characteristics of the binary mixture "bitumen: linseed oil". Flaxseed oil was chosen as a component of bitumen composition, which would provide the necessary adhesive and plastic properties.

Bitumen from which roofing materials are made are very sensitive to temperature fluctuations and various atmospheric influences. Their negative property is low frost, which makes the coating short-lived. We have studied the possibility of developing bitumen material which can be used for the production of cold-applied roofing materials. Thus, the second stage in the production of colddrawn bituminous materials was the study of a three-component bituminous composition "bitumen BNB 70/30 : linseed oil : rubber crumb". As the third component, used rubber crumb, which is obtained by crushing exhaust tire.

The study of the temperature dependence of the softening of a three-component mixture from its composition demonstrated the mutual influence of the components. It has been established that

$2^{\text {nd }}$ INTERNATIONAL SCIENTIFIC CONFERENCE “CHEMICAL TECHNOLOGY AND ENGINEERING - 2”, JUNE 24-28 ${ }^{\text {TH }}, 2019$, LVIV, UKRAINE 
with the increase in the content of rubber crumb and the decrease in the content of linseed oil in the mixture, the softening temperature rises. It is also established that reducing the content of flaxseed oil and increasing the amount of rubber crumb in the mixture leads to a decrease in its penetration. The ductility of a three-component mixture increases with increasing flax content.

Maximum elasticity is achieved with the highest content of rubber crumb and the minimum amount of linseed oil. Studies have established that the flexibility at $-25^{\circ} \mathrm{C}$ is maintained at the content of flax oil in a mixture of more than $15 \%$ by weight, and the amount of rubber crumb to $12.5 \%$ by weight. If these requirements are not met, the bituminous material becomes fragile, which does not meet the requirements. It is also established that adhesion decreases with the addition of rubber crumb in all cases.

Analyzing the obtained results, an optimal composition of the three-component bitumen composition, which meets all the requirements for cold-rolled roofing bitumen, was determined. It was established that the content of bitumen BNB 70/30 in this composition should be 65.0-78.5\% by weight, the content of linseed oil $-12.5-22.5 \%$ by weight, the content of rubber crumb - 9.0$12,5 \%$ by weight.

Based on the obtained results, a bituminous composition for cold-drawing materials was obtained, consisting of $72.5 \%$ by weight. bitumen grade BNB 70/30, 17.5\% by weight linseed oil and $10.0 \%$ by weight of rubber crumb. Characteristics of such a composition are shown in Table. 1

Table 1

Characteristics of a bituminous composition for cold-rolled roofing material

\begin{tabular}{|l|c|c|}
\hline \multicolumn{1}{|c|}{ Index } & Values & $\begin{array}{c}\text { Requirements for } \\
\text { bitumen composition }\end{array}$ \\
\hline Softening temperature, $\mathrm{C}$ & 76,0 & $>70$ \\
\hline Ductility at $25^{\circ} \mathrm{C}, \mathrm{cm}$ & 3,2 & - \\
\hline Penetration at $25^{\circ} \mathrm{C}, 0.1 \mathrm{~mm}$ & 33,0 & - \\
\hline Elasticity, $\%$ & 53,0 & stands the test \\
\hline Low-temperature flexibility at at $-25^{\circ} \mathrm{C}$ & stands the test & stands the test \\
\hline Heat resistance at $60^{\circ} \mathrm{C}$ & stands the test & $>5.0$ \\
\hline Adhesion, N/cm ${ }^{2}$ & 5,6 & $<1.0$ \\
\hline Water absorbing, $\%$ & 0,15 & \\
\hline
\end{tabular}

\section{Conclusion}

On the basis of the results of the study of the dependence of the properties of three-component systems, a new type of bituminous composition for cold-applied roofing materials was obtained. The developed bitumen composition for cold-rolled roofing material using rubber crumb also meets the requirements set by us. Due to the elevated temperature softened, the roofing materials developed have high resistance in hot climatic conditions. Also, the optimal composition of the three-component bitumen composition was determined from the obtained results.

\section{References}

[1] I. Fryder, O. Grynyshyn, Yu. Khlibyshyn. "Usage of pyrolysis heavy resin for the petroleum bitumen production," Proceedings of the National Aviation University, vol. 4 (57), pp. 135138, 2013.

[2] A. Nagurskyy, Yu Khlibyshyn, O. Grynyshyn, "Bitumen compositions for cold applied roofing products," Chemistry \& Chemical Technology, Vol.11, №2, pp. 226-229, 2017. 